\title{
Maternal vitamin $D$ intake and mineral metabolism in mothers and their newborn infants
}

\author{
F COCKBURN, N R BELTON, R J PURVIS, M M GILES, J K BROWN, T L TURNER, \\ E M WILKINSON, J O FORFAR, W J M BARRIE, G S MCKAY, S J POCOCK
}

\begin{abstract}
Summary and conclusions
Pregnant women receiving daily supplements of $400 \mathrm{IU}$ $(10 \mu \mathrm{g})$ of vitamin $D_{2}$ from the 12th week of pregnancy had plasma calcium concentrations higher at 24 weeks but similar at delivery to those in control pregnant women who did not receive the supplements. Infants of the women receiving the supplements had higher calcium, lower phosphorus, and similar magnesium concentrations on the sixth day of life and a lower incidence of hypocalcaemia than infants of the control women. Plasma concentrations of 25-hydroxycholecalciferol, which showed a seasonal variation, were higher in mothers and infants in the treated group. Cord-blood calcium, magnesium, phosphorus, and 25-hydroxycholecalciferol concentrations correlated with maternal values at delivery. Breast-fed infants had higher calcium and magnesium and lower phosphorus and 25-hydroxycholecalciferol concentrations than artificially fed infants. A defect of dental enamel was found in a high proportion of infants (many of whom had suffered from hypocalcaemia) born to the control women.

These results suggest that vitamin $D$ supplementation during pregnancy would be beneficial for mothers, whose intake from diet and skin synthesis is appreciably less than 500 IU of vitamin D daily.
\end{abstract}

\section{Introduction}

Unmodified cows' milk with its high phosphorus content may precipitate neonatal hypomagnesaemic tetany,,$^{1-5}$ but this alone does not explain the increased incidence of neonatal tetany in male infants ${ }^{5-7}$ and infants born to mothers of higher parity and in lower socioeconomic groups. ${ }^{7}$ In addition there is an appreciable seasonal variation with an inverse relation between the mean daily hours of sunshine during the last three months of

\footnotetext{
Department of Child Life and Health, University of Edinburgh and Simpson Memorial Maternity Pavilion, Edinburgh EH9 1 UW

F COCKBURN, MD, FRCPED, senior lecturer (now professor of child health, University of Glasgow)

N R BELTON, PHD, CCHEMMRIC, senior lecturer

R J PURVIS, MRCP, DCH, lecturer (now consultant paediatrician, West Dorset Health Care District)

M M GILES, BSC, research biochemist

J K BROWN, MB, FRCPED, consultant paediatrician

T L TURNER, MB, MRCP, lecturer (now consultant paediatrician, Hull Royal Infirmary)

E M WILKINSON, SRN, HVC, health visitor

J O FORFAR, MD, FRCP, professor of child life and health

Edinburgh Dental Hospital, Edinburgh

W J M BARRIE, FDS, DORTH, orthodontic consultant
}

Department of Dental Surgery, University of Dundee, Dundee G S MCKAY, BDS, PHD, senior lecturer

Medical Computing and Statistics Unit, University of Edinburgh

S J POCOCK, BA, PHD, lecturer (now senior lecturer in medical statistics, department of clinical epidemiology and social medicine, Royal Free Hospital, London) pregnancy and the incidence of neonatal hypocalcaemic tetany. ${ }^{3}$ \& 8 9 $\mathrm{A}$ defect of dental enamel related to disturbed tooth development during the last three months of intrauterine life is commonly found in infants who suffer from neonatal hypocalcaemic tetany ${ }^{8}$ Neonatal tetany may also be associated with temporary hypoparathyroidism in the infant, which may be induced by hyperparathyroidism in the mother. ${ }^{10}$ Thus neonatal hypocalcaemia, neonatal hypoparathyroidism, and a defect of tooth enamel induced during late pregnancy are all associated and are probably due to vitamin $\mathrm{D}$ deficiency and secondary hyperparathyroidism ${ }^{8}$ in the mother during pregnancy. We therefore carried out a study to investigate whether vitamin $D$ supplementation during pregnancy is beneficial to mothers and their infants.

\section{Patients and methods}

Five hundred and six pregnant women assigned to one ward of the Simpson Memorial Maternity Pavilion, Edinburgh, during the nine months from September to May were given a daily dietary supplement of $400 \mathrm{IU}(10 \mu \mathrm{g})$ of vitamin $\mathrm{D}_{2}$ from about the 12 th week of pregnancy until delivery; a control group of 633 pregnant women assigned to another ward over the same period was given a placebo containing no vitamin $\mathrm{D}$. The two groups were comparable for social class, parity, and maternal age. Plasma concentrations of calcium, phosphorus, magnesium, total proteins, and 25-hydroxycholecalciferol were estimated in both groups at the 24th and 34th weeks of pregnancy and at delivery. Similar estimations were carried out on umbilical venous blood taken from the infants at birth and on capillary blood on the sixth day. $25-$ Hydroxycholecalciferol and total protein values were not obtained in all cases, the former because the assay is time consuming and the latter because the assay was introduced late into the study. We were often unable to obtain all blood samples from mother/baby pairs especially at the 24th week of pregnancy, when many mothers were in the care of their general practitioner. There is no evidence, however, that missing values biased the results. Additional information relating to each mother and infant was recorded on a standard form. Social class was determined within five groups.

Methods for estimating calcium, phosphorus, magnesium, and total protein concentrations were as described, ${ }^{11}$ while 25 -hydroxycholecalciferol concentrations were estimated by a modification of the method of Preece et al. ${ }^{12}$

\section{Results}

Table I shows the mean plasma concentrations of calcium, phosphorus, magnesium, total protein, and 25-hydroxycholecalciferol in the three maternal samples and two infant samples obtained in both groups. Table II shows the mean sixth-day infant concentrations related to group and type of feed, and table III shows the differences in sixth-day infant plasma calcium concentrations between the groups and sexes.

\section{CALCIUM}

There was a significant difference in calcium concentration between the two groups of women at 24 weeks (that is, about 12 weeks after the vitamin D was first taken) but not thereafter. No correlation existed among the three maternal calcium values in either group, but there was a substantial correlation between maternal and umbilical-vein 
TABLE I-Concentrations of minerals, 25-hydroxycholecalciferol, and protein in mothers and infants in both groups

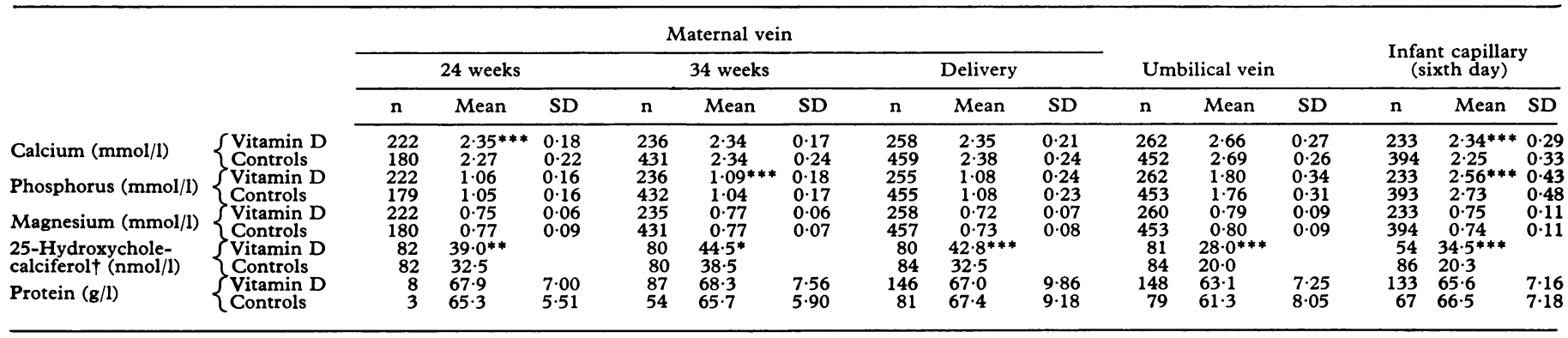

Significance of differences between groups (two-sample $t$ test): ${ }^{*} \mathrm{p}<0.05 ;{ }^{* *} \mathrm{p}<0.01 ;{ }^{* * *} \mathrm{p}<0.001$.

25-Hydroxycholecalciferol has a very skew distribution. To prevent large concentrations having an undue influence on comparisons each of the "means" quoted is the cube of the mean cube root of the concentrations.

calciferol: $1 \mathrm{nmol} / 1 \approx 40 \mathrm{ng} / 100 \mathrm{ml}$.

TABLE II-Influence of infant feed and maternal vitamin D intake on infant capillary concentrations on day 6

\begin{tabular}{|c|c|c|c|c|c|c|c|c|c|c|c|c|}
\hline & \multicolumn{6}{|c|}{ Vitamin D } & \multicolumn{6}{|c|}{ Controls } \\
\hline & \multicolumn{3}{|c|}{ Breast milk } & \multicolumn{3}{|c|}{ Artificial milk } & \multicolumn{3}{|c|}{ Breast milk } & \multicolumn{3}{|c|}{ Artificial milk } \\
\hline & $\mathrm{n}$ & Mean & SD & $\mathrm{n}$ & Mean & SD & $\mathbf{n}$ & Mean & SD & $\mathbf{n}$ & Mean & SD \\
\hline $\begin{array}{l}\text { 25-Hydroxycholecalciferol* (nmol/l) } \\
\text { Calcium (mmol/1) } \\
\text { Phosphorus (mmol/1) } \\
\text { Magnesium (mmol/1) } \\
\text { Protein }(\mathrm{g} / \mathrm{l})\end{array}$ & $\begin{array}{l}12 \\
64 \\
63 \\
64 \\
39\end{array}$ & $\begin{array}{c}25 \cdot 2 \\
2 \cdot 45 \\
2 \cdot 32 \\
0 \cdot 80 \\
65 \cdot 6\end{array}$ & $\begin{array}{l}0 \cdot 29 \\
0 \cdot 38 \\
0 \cdot 10 \\
6 \cdot 3\end{array}$ & $\begin{array}{r}41 \\
169 \\
170 \\
169 \\
94\end{array}$ & $\begin{array}{c}34 \cdot 4 \\
2 \cdot 30 \\
2 \cdot 65 \\
0 \cdot 73 \\
65 \cdot 6\end{array}$ & $\begin{array}{l}0.28 \\
0.42 \\
0 \cdot 10 \\
7 \cdot 5\end{array}$ & $\begin{array}{r}22 \\
102 \\
102 \\
102 \\
15\end{array}$ & $\begin{array}{c}15 \cdot 4 \\
2 \cdot 41 \\
2 \cdot 52 \\
0 \cdot 79 \\
67 \cdot 3\end{array}$ & $\begin{array}{l}0.32 \\
0.42 \\
0.11 \\
6.9\end{array}$ & $\begin{array}{r}57 \\
285 \\
291 \\
292 \\
52\end{array}$ & $\begin{array}{c}20 \cdot 1 \\
2 \cdot 20 \\
2 \cdot 81 \\
0 \cdot 73 \\
66 \cdot 2\end{array}$ & $\begin{array}{l}0 \cdot 32 \\
0 \cdot 48 \\
0 \cdot 10 \\
7 \cdot 3\end{array}$ \\
\hline
\end{tabular}

* See footnote to table I.

Conversion: SI to traditional units-25-Hydroxycholecalciferol: $1 \mathrm{nmol} / 1 \approx 40 \mathrm{ng} / 100 \mathrm{ml}$. Calcium: $1 \mathrm{mmol} / 1 \approx 4 \mathrm{mg} / 100 \mathrm{ml}$. Phosphorus: $1 \mathrm{mmol} / 1 \approx 3 \cdot 1 \mathrm{mg} / 100 \mathrm{ml}$. Magnesium: $1 \mathrm{mmol} / 1 \approx 2 \cdot 4 \mathrm{mg} / 100 \mathrm{ml}$.

TABLE III-Difference between sexes in mean plasma calcium concentration in infant capillary samples on day 6

\begin{tabular}{lcccccc}
\hline & \multicolumn{2}{c}{ Vitamin D } & & \multicolumn{2}{c}{ Control } \\
\cline { 2 - 3 } \cline { 6 - 7 } & Male & Female & & Male & Female \\
\hline $\begin{array}{l}\text { No of infants } \\
\text { Mean ( } \pm \text { SD }) \text { calcium }\end{array}$ & $2.30 \pm 0.28$ & $2.38 \pm 0.28$ & & $2.23 \pm 0.34$ & $2.27 \pm 0.33$ \\
$\begin{array}{l}\text { No (\%) with } \\
\text { hypocalcaemia* }\end{array}$ & $9(8)$ & $6 \%$ & $4(4)$ & & $33(16)$ & $20(11)$ \\
& & $6 \%$ & & & \multicolumn{2}{c}{$13 \%$}
\end{tabular}

*Plasma calcium concentration $<1.85 \mathrm{mmol} / 1(7.4 \mathrm{mg} / 100 \mathrm{ml})$. Conversion: SI to traditional units-Calcium: $1 \mathrm{mmol} / 1 \approx 4 \mathrm{mg} / 100 \mathrm{ml}$.

calcium concentrations at delivery $(r=0.242$ and 0.368 respectively in women receiving vitamin $\mathrm{D}$ and controls). Cord-blood values were significantly higher than maternal delivery and infant sixth-day values ( $p<0.00001$ for all groups).

Infant sixth-day calcium concentration was significantly higher in the group receiving the supplements than the controls (table I). Thirteen out of 233 infants $(6 \%)$ in the group receiving supplements were hypocalcaemic on the sixth day (plasma calcium $<1.85 \mathrm{mmol} / 1$ $(7.4 \mathrm{mg} / 100 \mathrm{ml})$ - table III) compared with 53 out of $394(13 \%)$ in the control group $\left(\chi^{2}=8.82, p<0.005\right)$.

Table II shows that breast-fed infants in both groups had higher calcium concentrations than artificially fed infants $(p<0.00001)$. Only two out of 64 breast-fed infants $(3 \%)$ born to women receiving the supplements became hypocalcaemic compared with 47 out of 285 artificially fed infants $(16 \%)$ born to control women. Table III shows that male infants had lower mean plasma calcium concentrations than female infants $(p=0.02)$.

Further multiple regression analysis showed that the effects of feed, vitamin $\mathrm{D}$ supplementation, and sex were additive and that the sixthday plasma calcium concentration in infants could be predicted by the formula: sixth-day calcium $(\mathrm{mmol} / \mathrm{l})=2 \cdot 17+0.193$ if breast fed + 0.084 if mother given vitamin $D+0.063$ if female, with a standard error of prediction of $0.305 \mathrm{mmol} / \mathrm{l}$. Thus the greatest influence on infant plasma calcium concentration is type of feed.

Maternal age, parity, type of delivery, Apgar score, social class, pre-eclampsia, birth weight, and gestational age showed no significant association with sixth-day calcium concentration once the effects of feed, vitamin D supplementation, and sex were allowed for. For instance, the apparent correlation between social class and infant calcium concentration may be explained by the lower incidence of breast feeding in classes 4 and 5 .

PHOSPHORUS

During pregnancy plasma phosphorus concentrations remained fairly constant and were not influenced by maternal vitamin $D$ except at 34 weeks, when higher concentrations were present in the women receiving the supplement (table 1 ). There was no significant difference in cord values, but infants of the control mothers had considerably higher mean values on the sixth day $(p<0.0001)$. Furthermore, in both groups artificial feeding raised the mean phosphorus concentration (table II) as compared with breast feeding $(p<0.00001)$. In both groups maternal and cord phosphorus concentrations were correlated, and infant plasma calcium and phosphorus concentrations in sixth-day samples showed a negative correlation.

\section{MAGNESIUM}

Maternal magnesium concentrations were not influenced by the vitamin $\mathrm{D}$ intake, and mean values at delivery in both groups were below those observed at 24 and 34 weeks (table I). Cord values were significantly greater than delivery values and correlated strongly with them. Multiple regression analysis of the various maternal and infant factors possibly affecting infant sixth-day magnesium concentrations showed that only type of feed had a significant influence (table II; $p<0.00001$ ). Calcium and magnesium concentrations in infant sixthday blood showed a strongly positive correlation $(r=0.6$ in both groups).

\section{PROTEIN}

Plasma protein concentrations did not change significantly during pregnancy nor differ between the groups. Infant sixth-day calcium and protein concentrations were positively correlated, but protein showed no correlation with other variables. 


\section{5-HYDROXYCHOLECALCIFEROL}

Maternal plasma concentrations of 25-hydroxycholecalciferol were significantly higher in the mothers who received vitamin D, and this difference was maintained in infant cord and sixth-day values (table I). Maternal values were significantly higher than infant values. Plasma concentrations increased between birth and the sixth day in infants born to mothers who received vitamin D supplements but not in infants of control mothers. On the sixth day, concentrations were higher in artificially fed than breast-fed infants $(p<0.01)$ and higher in the group that received the supplement with both types of feed The sex of the infant did not influence sixth-day values.

There was a highly significant correlation between maternal and cord values at delivery ( $r=0.71$ in both groups), with maternal vein concentration almost always higher than umbilical vein concentration. The correlation between maternal samples at 24 weeks and delivery was significant in the group receiving vitamin $\mathrm{D}(\mathrm{r}=0.46)$ but not in the control group $(r=0.06)$, no correction being made for seasonal periodicity.

In all samples in both groups there was a seasonal trend in concentrations of 25-hydroxycholecalciferol with peak values in July and August. The figure shows this trend for the umbilical vein samples. In

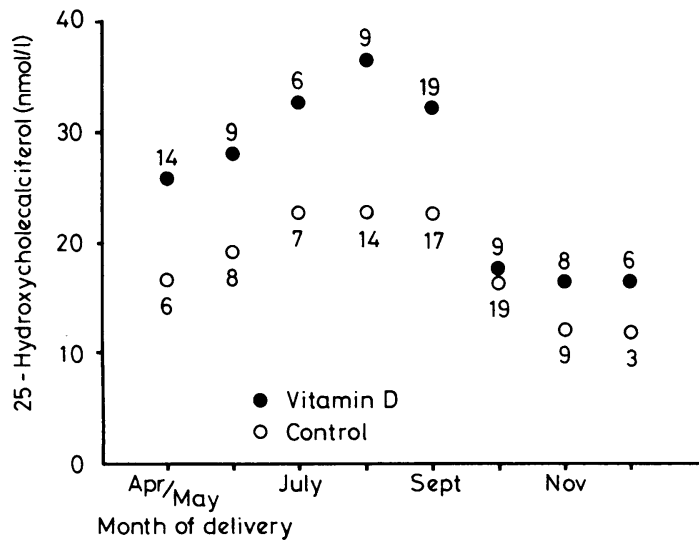

Seasonal trend in mean concentration of 25-hydroxycholecalciferol in umbilical vein plasma. (Figures indicate numbers of samples.)

Conversion: SI to traditional units-25-hydroxycholecalciferol: $1 \mathrm{nmol} / 1 \approx 40 \mathrm{ng} / 100 \mathrm{ml}$

maternal samples, particularly at 24 weeks' gestation, the seasonal trend was less pronounced in the group receiving the supplements than in the control group. Differences between maternal 25-hydroxycholecalciferol concentrations in both groups remained similar throughout pregnancy. The apparent peak at 34 weeks occurred because most of these samples were collected during the summer six months (April-September).

An estimation of dietary vitamin $D$ intake based on recall in a sample of 84 mothers questioned at 34 weeks showed that their mean daily vitamin D intake was 91 IU $(2 \cdot 3 \mu \mathrm{g})$ per day.

\section{CONVULSIONS}

Tetanic convulsions occurred in eight infants $(0.7 \%)$ : two of the 506 infants of treated mothers $(0.4 \%)$ and six of the 633 control infants $(0.9 \%)$; this difference is not significant. All eight were artificially fed; five were male.

\section{DENTAL ENAMEL}

Sixty-one infants had their teeth examined in their third year (mean age 2.6 years) by a paediatric dentist (WJMB), who was unaware of the maternal vitamin $D$ state or of the calcium concentrations in the infant on the sixth day. Thirty-one of these infants had been born to control mothers and had been hypocalcaemic: $15(48 \%)$, of whom two had been breast-fed, had an enamel defect. The remaining 30 infants had been born to mothers receiving the supplements and were matched as closely as possible with the previous 31 for month of birth, type of feed, sex, social class, parity, and age of mother in that order: only two $(7 \%)$ showed any enamel defect in their teeth. This difference is highly significant $\left(\chi^{2}=13 \cdot 2, \mathrm{p}<0.001\right)$.

\section{Discussion}

The recognition in the 1950 s of an apparently new disease, idiopathic hypercalcaemia of infancy, ${ }^{13} 14$ and subsequently of its aetiological association with excess vitamin $D$ intake ${ }^{15}$ led to a major reappraisal of the policy of vitamin $\mathrm{D}$ supplementation in infants and pregnant women. Such supplementation of pregnant mothers fell out of favour, and in Edinburgh routine welfare distribution stopped in 1964. Subsequently tetanic convulsions in the newborn infant have appeared to be on the increase. ${ }^{16-18}$

Concentrations of 25-hydroxycholecalciferol tend to be lower in pregnant than non-pregnant women. ${ }^{19}$ The precise vitamin $\mathrm{D}$ requirement of pregnant mothers is not known but is probably of the order of 500-700 IU per day. ${ }^{20}{ }^{21}$ In this study, as in the study of Turton et al, ${ }^{19}$ many mothers not receiving vitamin $D$ supplements were found to have a dietary intake of vitamin $D$ of less than 100 units per day. Both of our groups of women showed a seasonal variation in concentrations of 25-hydroxycholecalciferol. Thus 400 added units of vitamin D did not prevent seasonal variation; nor did it abolish hypocalcaemia and convulsions, although it reduced their incidence. Supplementation also raised the plasma calcium concentration in mothers and infants and lowered the phosphorus concentration.

A specific type of enamel defect of the primary dentition determined prenatally is associated with neonatal hypocalcaemia. ${ }^{822}$ Nearly half $(48 \%)$ of the hypocalcaemic infants born to control mothers suffered from this defect.

Thus the control mothers, who were deficient in vitamin $D$, gave birth to infants more prone to hypocalcaemia, tetanic convulsions, and enamel defects of the teeth. In the mothers given the supplement, who received a total of about 500 units of vitamin $\mathrm{D}$ per day, neonatal hypocalcaemia and enamel defect were not wholly abolished. Thus many pregnant mothers apparently require more than 500 units of vitamin D per day. Arguments for and against increased vitamin $D$ in pregnancy have been adduced recently. ${ }^{23-26}$

This study also confirms that breast milk plays an important part in protecting against neonatal hypocalcaemia, hypomagnesaemia, and hyperphosphataemia. When an infant is artificially fed the adverse effect of such feeding in respect of disturbed mineral metabolism is to some extent offset but not abolished by administration of a vitamin $\mathrm{D}$ supplement of 400 units daily to the mother.

Requests for reprints should be sent to Dr N R Belton, Department of Child Life and Health, University of Edinburgh, 17 Hatton Place, Edinburgh EH9 1UW.

\section{References}

1 Gittleman IF, Pincus JB. Influence of diet on the occurrence of hyperphosphatemia and hypocalcemia in the newborn infant. Pediatrics 1951; 8:778-87.

${ }^{2}$ Cockburn F, Brown JK, Belton NR, Forfar JO. Neonatal convulsions associated with primary disturbance of calcium phosphorus and magnesium metabolism. Arch Dis Child 1973;48:99-108.

${ }^{3}$ Keen JH. Significance of hypocalcaemia in neonatal convulsions. Arch Dis Child 1969;44:356-61.

4 Oppé TE, Redstone D. Calcium and phosphorus levels in healthy newborn infants given various types of milk. Lancet $1968 ; \mathrm{i}: 1045-8$.

5 Pincus JB, Gittleman IF, Marius N, Bachra B. The effect of graded doses of vitamin $\mathrm{D}$ on the serum calcium and phosphorus levels. Am $\mathcal{F} D$ is Child 1958;96:16-22.

- Saville PD, Kretchmer N. Neonatal tetany: a report of 125 cases and review of the literature. Biol Neonate $1960 ; 2: 1-18$.

7 Roberts SA, Cohen MD, Forfar JO. Antenatal factors associated with neonatal hypocalcaemic convulsions. Lancet 1973 ;ii :809-11. 
${ }^{8}$ Purvis RJ, Barrie WJM, MacKay GS, et al. Enamel hypoplasia of the teeth associated with neonatal tetany: a manifestation of maternal vitamin D deficiency. Lancet $1973 ; \mathrm{ii}: 811-4$.

- Todd WR, Chuinard RG, Wood MT. Blood calcium and phosphorus in the newborn. Am $\mathcal{F}$ Dis Child 1939;57:1278-87.

${ }^{10}$ Cushard WG, Crichton MA, Canterbury JM, Reiss E. Physiologic hyperparathyroidism in pregnancy. $\mathcal{f}$ Clin Endocrinol Metab 1972;34: 767-71.

11 Belton NR, Cockburn F, Forfar JO, et al. Clinical and biochemical assessment of a modified evaporated milk for infant feeding. Arch Dis Child 1977;52:167-75.

12 Preece MA, O'Riordan JLH, Lawson DEM, Kodicek E. A competitive protein-binding assay for 25-hydroxycholecalciferol and 25-hydroxyergocalciferol in serum. Clin Chim Acta 1974;54:235-42.

13 Lightwood R. Idiopathic hypercalcaemia in infants with failure to thrive. Proc $R$ Soc Med 1952;45:401.

14 Lightwood R. Idiopathic hypercalcaemia in infants with failure to thrive. Arch Dis Child 1952;27:302-3.

15 British Paediatric Association. Report. Infantile hypercalcaemia, nutritional rickets and infantile scurvy in Great Britain. Br Med $\mathcal{f} 1964$;i:1659-61.

16 Baum D, Cooper L, Davies PA. Hypocalcaemic fits in neonates. Lancet $1968 ; i: 598-9$.

17 Pugh RJ. Hypocalcaemic fits in neonates. Lancet $1968 ; \mathrm{i}: 644$.

18 Eades S. Hypocalcaemic fits in neonates. Lancet $1968 ; \mathrm{i}: 644-5$.
19 Turton CWG, Stanley P, Stamp TCB, Maxwell JD. Altered vitamin D metabolism in pregnancy. Lancet $1977 ; \mathrm{i}: 222-5$.

${ }^{20}$ Pitkin RM, Kaminetzky HA, Newton M, Pritchard JA. Maternal nutrition. A selective review of clinical topics. Obstet Gynecol 1972;40 : 773-85.

${ }^{21}$ Paunier L, Lacourt G, Pilloud P, Schlaeppi P, Sizonenko PF. 25-hydroxyvitamin $\mathrm{D}$ and calcium levels in maternal, cord and infant serum in relation to vitamin D intake. Helv Paediatr Acta 1978;33:95-103.

22 Stimmler L, Snodgrass GJAI, Jaffe E. Dental defects associated with neonatal symptomatic hypocalcaemia. Arch Dis Child 1973;48:217-20.

${ }^{23}$ Rosen JF, Roginsky M, Nathenson G, Finberg MD. 25-hydroxyvitamin $D$ plasma levels in mothers and their premature infants with neonatal hypocalcaemia. Am $\mathcal{F}$ Dis Child 1974;127:220-3.

24 Dent CE, Gupta MM. Plasma 25-hydroxyvitamin D levels during pregnancy in Caucasians and in vegetarian and non-vegetarian Asians. Lancet 1975 ;ii : 1057-60.

${ }^{25}$ Glasgow JFT, Thomas PS. Rachitic respiratory distress in small preterm infants. Arch Dis Child 1977;52:268-73.

${ }^{26}$ Hillman LS, Haddad JG. Perinatal vitamin D metabolism. III Factors influencing late gestational human serum 25-hydroxyvitamin D. $A m \mathcal{F}$ Obstet Gynecol 1976;125:196-200.

(Accepted 22 April 1980)

\title{
Rate of digestion of foods and postprandial glycaemia in normal and diabetic subjects
}

\author{
DAVID J A JENKINS, THOMAS M S WOLEVER, RODNEY H TAYLOR, HAMID GHAFARI, \\ ALEXANDRA L JENKINS, HELEN BARKER, MARK J A JENKINS
}

\section{Summary and conclusions}

Carbohydrate portions ( $2 \mathrm{~g}$ ) of lentils, soya beans, and wholemeal bread were incubated for three hours with human digestive juices and the effect of digestibility on blood glucose examined. Lentils and soya beans released only $39 \%$ and $8 \%$ respectively of the sugars and oligosaccharides liberated from bread. In healthy volunteers $50 \mathrm{~g}$ carbohydrate portions of cooked lentils and soya beans raised blood glucose concentrations by only $42 \%$ $(p<0.001)$ and $14 \%(p<0.001)$ of the bread value. There was a similar response in diabetics.

These results suggest that rate of digestion might be an important factor determining the rise in blood glucose concentration after a meal and that supplementing chemical analysis with in-vitro and in-vivo food testing might permit identification of especially useful foods for diabetics.

Department of the Regius Professor of Medicine, Radcliffe Infirmary, Oxford

DAVID J A JENKINS, DM, research associate

University Laboratory of Physiology, Oxford OX1 3PT

THOMAS M S WOLEVER, MSC, research fellow

HAMID GHAFARI, MSC, BDA fellow

ALEXANDRA L JENKINS, research associate

MARK J A JENKINS, research associate

Gastroenterology Department, Central Middlesex Hospital, London NW10

RODNEY H TAYLOR, MRCP, honorary senior registrar; research fellow HELEN BARKER, BSC, SRD, research dietitian

\section{Introduction}

Studies suggest that the postprandial rise in blood glucose concentration may be influenced by the rate of carbohydrate absorption. ${ }^{1}$ Work with various dietary fibres ${ }^{1}$ and food starches ${ }^{2}$ emphasised that great differences in rates of digestion and absorption may exist between foods. Hence foods that liberate their carbohydrate slowly might be of use to diabetics by reducing the rise in blood glucose values after a meal.

We have examined digestibility and the effect on blood glucose of two different types of foods-namely, bread, a cereal product and traditionally a staple food in the West; and two leguminous seeds, lentils and soya beans, representing foods much more commonly eaten in those parts of the world where diabetes is less common.

\section{Methods \\ IN-VITRO STUDIES}

Carbohydrate portions $(2 \mathrm{~g})$ of cooked soya beans and lentils, ground to a smooth paste, and finely crumbed wholemeal bread (see table I) were mixed separately with $2.5 \mathrm{ml}$ fresh pooled human saliva and $7.5 \mathrm{ml}$ human postprandial jejunal juice (Lundh test-juice pooled from samples of mean tryptic activity exceeding $15 \mathrm{IU} / 1$ and stored at $-20^{\circ} \mathrm{C}$ ). Distilled water was added to the bread and lentils to make the final volume of all foods up to $30 \mathrm{ml}$. Food and digestive juices were then mixed well and placed in dialysis bags made of $13 \mathrm{~cm}$ strips of dialysis tubing (Visking size 9-36/32", Medicell International, London). Each bag was suspended in separate stirred water baths containing $800 \mathrm{ml}$ distilled water at $37^{\circ} \mathrm{C}$. Other experiments with isotonic phosphate buffer $\mathrm{nH} 7 \cdot 25$ gave similar results. Aliquots of dialysates were taken at $0,1,2$, and 3 hours for analysis of glucose, maltose, and oligosaccharides. Glucose was analysed by a standard enzymatic technique. ${ }^{3}$ Maltose and oligosaccharides were analysed together as glucose $e^{3}$ after acid hydrolysis with an equal volume of $10 \mathrm{M} \mathrm{HCl}$ for one hour at $75^{\circ} \mathrm{C}$ and neutralisation with $\mathrm{NaOH}$. We 